Gothic Modernisms 
Also by Andrew Smith

BRAM STOKER: History, Psychoanalysis and the Gothic (co-editor with William Hughes)

DRACULA AND THE CRITICS

FICTIONS OF UNEASE: The Gothic from Otranto to the X-Files (co-editor with William Hughes and Diane Mason)

GOTHIC RADICALISM: Literature, Philosophy and Psychoanalysis in the Nineteenth Century

Also by Jeff Wallace

CHARLES DARWIN'S ORIGIN OF SPECIES: New Interdisciplinary Essays (co-editor with David Amigoni)

RAYMOND WILLIAMS NOW: Knowledge, Limits and the Future (co-editor with Rod Jones and Sophie Nield) 


\section{Gothic Modernisms}

Edited by

Andrew Smith

Senior Lecturer in English

University of Glamorgan

and

Jeff Wallace

Senior Lecturer in English

University of Glamorgan 
Editorial matter and selection (C) Andrew Smith and Jeff Wallace 2001

Chapter 7 (C) Jeff Wallace 2001

Chapter 9 @ Andrew Smith 2001

Chapters 1-6, 8, 10-12 @ Palgrave Publishers Ltd 2001

Softcover reprint of the hardcover 1st edition 2001 978-0-333-91873-9

All rights reserved. No reproduction, copy or transmission of this publication may be made without written permission.

No paragraph of this publication may be reproduced, copied or transmitted save with written permission or in accordance with the provisions of the Copyright, Designs and Patents Act 1988, or under the terms of any licence permitting limited copying issued by the Copyright Licensing Agency, 90 Tottenham Court Road, London W1P OLP.

Any person who does any unauthorised act in relation to this publication may be liable to criminal prosecution and civil claims for damages.

The authors have asserted their rights to be identified as the authors of this work in accordance with the Copyright, Designs and Patents Act 1988.

First published 2001 by

\section{PALGRAVE}

Houndmills, Basingstoke, Hampshire RG21 6XS and 175 Fifth Avenue, New York, N. Y. 10010

Companies and representatives throughout the world

PALGRAVE is the new global academic imprint of St. Martin's Press LLC Scholarly and Reference Division and Palgrave Publishers Ltd (formerly Macmillan Press Ltd).

ISBN 978-1-349-42365-1

ISBN 978-0-333-98523-6 (eBook)

DOI $10.1057 / 9780333985236$

This book is printed on paper suitable for recycling and made from fully managed and sustained forest sources.

A catalogue record for this book is available from the British Library.

Library of Congress Cataloging-in-Publication Data

Gothic modernisms / edited by Andrew Smith and Jeff Wallace. p. $\mathrm{cm}$.

Includes bibliographical references and index.

1. English fiction-20th century-History and criticism. 2. Modernism (Literature)—Great Britain. 3. Psychological fiction, English-History and criticism. 4. Woolf, Virginia, 1882-1941-Criticism and interpretation. 5. Barnes, Djuna-Criticism and interpretation. 6. Modernism (Literature)-United States. 7. Influence (Literary, artistic, etc.) 8. Gothic revival (Literature) 9. Motion pictures-History. 10. Self in literature. I. Smith, Andrew, 1964- II. Wallace, Jeff, 1958PR888.M63 G67 2001

823 '.9109112-dc21 
Nat Benson

Charles Bignall

In memoriam 
This page intentionally left blank 


\section{Contents}

Acknowledgements

Notes on the Contributors

Introduction: Gothic Modernisms: History, Culture and Aesthetics

Andrew Smith and Jeff Wallace

1 Hungry Ghosts and Foreign Bodies

David Punter

2 The 'Spectrality Effect' in Early Modernism

David Glover

3 'Psychical' Cases: Transformations of the Supernatural in Virginia Woolf and May Sinclair

David Seed

4 The Ghost and the Omnibus: the Gothic Virginia Woolf Judith Wilt

5 Strolling in the Dark: Gothic Flânerie in Djuna Barnes's Nightwood

Avril Horner and Sue Zlosnik

6 'Thick Within Our Hair': Djuna Barnes's Gothic Lovers Deborah Tyler-Bennett

7 'The stern task of living': Dubliners, Clerks, Money and Modernism

Jeff Wallace

8 The Modernist Abominations of William Hope Hodgson Kelly Hurley

9 Vampirism, Masculinity and Degeneracy: D. H. Lawrence's Modernist Gothic Andrew Smith

10 Arctic Masks in a Castle of Ice: Gothic Vorticism and Wyndham Lewis's Self Condemned

Francesca Orestano 
11 Metropolis and the Modernist Gothic Nigel Morris

12 Hollywood Gothic/Gothic Hollywood: the Example of Billy Wilder's Sunset Boulevard Julian Wolfreys 


\section{Acknowledgements}

We would like to thank Charmian Hearne at Palgrave for her enthusiasm and for her advice, and to thank Eleanor Birne for her patience. We would like to thank Colin Gent and Helen Gunter for their technical support. Finally we would like to thank Joanne Benson and Frances Sloan for their love, support and tolerance throughout the editing process. 


\section{Notes on the Contributors}

David Glover read for his first degree at London University, gained his MA from the University of Manitoba and his PhD from the University of Sheffield. He is Senior Lecturer in English at the University of Southampton. He is the author of Vampires, Mummies and Liberals: Bram Stoker and the Politics of Popular Fiction (1996) and co-author (with Cora Kaplan) of Genders in the Routledge New Critical Idiom series.

Avril Horner is Professor of English and Director of the European Studies Research Institute at the University of Salford. Her publications include Daphne du Maurier: Writing, Identity and the Gothic Imagination (with Sue Zlosnik, 1998) and Body Matters: Feminism, Textuality, Corporeality (edited with Angela Keane, 2000). She is currently working on Gothic and the Comic Turn (with Sue Zlosnik) and an edited collection, European Gothic: a Spirited Exchange, 1760-1960.

Kelly Hurley completed her PhD in English at Stanford University. She is an Associate Professor of English at the University of Colorado at Boulder. She is the author of The Gothic Body: Sexuality, Materialism and Degeneration at the Fin de Siècle (1996) and is presently working on a further book, provisionally entitled Terra Incognita: Late Victorian Imperialism and 'Lost World' Fictions.

Nigel Morris studied at the Universities of Stirling, California (Santa Barbara), Keele, Aberystwyth and London, and is currently Senior Lecturer in Media Theory at the University of Lincolnshire and Humberside. He has published on American and British (including Welsh) cinema and on Lawrence and film. He is completing a book on the films of Spielberg and various entries for A Dictionary of Literary Modernism (both for Greewood Press).

Francesca Orestano studied at the University of Palermo. She is currently acting Professor of English Literature and Comparative Literature at the University of Milan. She has published widely on Ruskin and Dickens and has recently completed a monograph entitled Slaves to Images: English Literature from Gilpin to Wyndham Lewis. 
David Punter read English at Cambridge, and after posts at East Anglia, in Hong Kong and at Stirling University, is now Professor of English at Bristol University. His twenty published books include The Literature of Terror (1980; revised 1996), The Romantic Unconscious (1988) and Gothic Pathologies (1998). Two further books, Writing the Passions and Postcolonial Imaginings were published in 2000.

David Seed took degrees at Cambridge, Leicester and Hull University. He is Reader in the English Department at Liverpool University and is series editor for Liverpool University Press Science Fiction Texts and Studies. His books include monographs on Thomas Pynchon (1988), Joseph Heller (1989), Rudolph Wurlitzer (1990) and James Joyce (1992). He is the author of American Science Fiction and the Cold War (1999), and is currently working on a study of representations of brainwashing in fiction and film.

Andrew Smith completed his PhD at the University of Southampton. He is Senior Lecturer in English at the University of Glamorgan. His publications include Gothic Radicalism: Literature, Philosophy and Psychoanalysis in the Nineteenth Century (2000) and Bram Stoker: History, Psychoanalysis and the Gothic (edited with William Hughes, 1998). He is currently working on a monograph on masculinity and monstrosity at the fin de siècle.

Deborah Tyler-Bennett completed her $\mathrm{PhD}$ at the University of Leicester. She is a poet and lecturer who has taught at Sheffield Hallam, De Montfort and Loughborough University. She is the author of Edith Sitwell: the Forgotten Modernist (1996) and has published widely on Djuna Barnes and Elizabeth Sharp. Her poetry has been published in a range of journals and she is the editor of the poetry journal, The Coffee House.

Jeff Wallace gained his PhD from the University of Kent. He is Senior Lecturer in English at the University of Glamorgan. Publications include Charles Darwin's Origin of Species: New Interdisciplinary Essays (edited with David Amigoni, 1995) and Raymond Williams Now: Knowledge, Limits and the Future (edited with Sophie Nield and Rod Jones, 1997). He is contributions editor of Key Words: Journal of Cultural Materialism, and joint series editor of MUP's Text in Culture. He is currently writing a monograph on D. H. Lawrence, science and the posthuman. 
Judith Wilt is Professor of English at Boston College. She teaches and writes in the field of nineteenth-century British fiction, women's studies, popular culture genres, and religion and literature. She is the author of four books of criticism, including Ghosts of the Gothic: Austen, Eliot and Lawrence (1980), and Abortion, Choice and Contemporary Fiction: the Armageddon of the Maternal Instinct (1990).

Julian Wolfreys received his BA and his DPhil from the University of Sussex. He is an Associate Professor of English at the University of Florida. His publications include Readings, Writing London: the Trace of the Urban Text from Blake to Dickens, and Peter Ackroyd: the Ludic and Labyrinthine Text (with Jeremy Gibson).

Sue Zlosnik graduated in Government from LSE and went on to postgraduate work in literature at the Universities of Cardiff and Manchester. She is now Associate Dean of Arts at Liverpool Hope University College. Her long-established research partnership with Avril Horner has produced two books (most recently, Daphne du Maurier: Writing, Identity and the Gothic Imagination [1997]). They are currently working on Gothic and the Comic Turn. 